\title{
PENGGUNAAN CAPITAL ASSET PRICING MODEL DALAM MENENTUKAN EKSPEKTASI RETURN PADA SAHAM LQ45
}

\author{
CINDYANA ALDRIFISIA, HAZMIRA YOZZA, DODI DEVIANTO \\ Jurusan Matematika, \\ Fakultas Matematika dan Ilmu Pengetahuan Alam, Universitas Andalas, \\ Kampus Unand Limau Manis, Padang, Indonesia \\ email : cindyaldrifisia@gmail.com
}

\begin{abstract}
Abstrak. Capital Asset Pricing Model merupakan salah satu model yang digunakan untuk mengestimasi ekspektasi return beserta risiko dari suatu investasi. Pada Capital Asset Pricing Model nilai ekspektasi return saham ditentukan dalam keadaan equilibrium, dan risiko saham diukur dengan beta sebagai risiko sistematis saham. Dalam penelitian ini Capital Asset Pricing Model digunakan untuk menentukan ekspektasi return dan risiko untuk saham-saham yang konsisten tergabung dalam Indeks LQ45 periode Februari 2017 sampai Januari 2018. Hasil perhitungan menunjukkan bahwa saham dengan nilai beta yang rendah memiliki nilai ekspektasi return yang rendah, dan sebaliknya. Hal ini membuktikan bahwa terdapat hubungan positif dan linier antara risiko sistematis dengan ekspektasi return.
\end{abstract}

Kata Kunci: Capital Asset Pricing Model, return, ekspektasi return, beta

\section{Pendahuluan}

Investasi adalah komitmen atas sejumlah dana atau sumber daya lainnya yang dilakukan pada saat ini, dengan tujuan memperoleh sejumlah keuntungan di masa datang [7]. Seiring dengan adanya prinsip pasar bebas dewasa ini, investasi dalam bentuk kepemilikan aset finansial sudah banyak diminati oleh masyarakat Indonesia. Salah satu aset finansial yang paling populer adalah stocks atau saham. Saham adalah surat berharga yang merupakan tanda kepemilikan seseorang atau badan terhadap suatu perusahaan [2]. Dengan berinvestasi saham, investor mengharapkan suatu hasil yang diperoleh dari investasi yang dikenal dengan ekspektasi return.

Pada umumnya investor tidak tahu dengan pasti hasil yang akan diperoleh dari investasi yang dilakukannya, sehingga terdapat kemungkinan hasil yang diperoleh menyimpang dari yang diharapkan. Dalam keadaan ini dikatakan bahwa investor tersebut menghadapi risiko dalam investasi. Keputusan investasi tidak dapat hanya mengandalkan pada tingkat keuntungan yang diharapkan, namun juga perlu memperhatikan unsur risikonya. Apabila investor mengharapkan untuk memperoleh tingkat keuntungan yang tinggi, maka ia harus bersedia menanggung risiko yang tinggi pula. Untuk mengurangi risiko tersebut, hal yang dapat ia lakukan adalah memperkirakan berapa keuntungan yang diharapkan dari investasinya, dan seberapa jauh kemungkinan hasil yang sebenarnya nanti akan menyimpang dari hasil yang diharapkan. 
Salah satu model yang dapat digunakan untuk mengestimasi nilai return yang diharapkan atau ekspektasi return beserta risiko dari suatu investasi adalah Capital Asset Pricing Model. Pada Capital Asset Pricing Model nilai ekspektasi return saham ditentukan pada keadaan equilibrium, dan risiko saham diukur dengan beta sebagai risiko sistematis saham.

\section{Saham}

Saham didefinisikan sebagai surat tanda bukti penyertaan kepemilikan modal pada suatu perusahaan tertentu [2]. Saham berwujud selembar kertas yang menerangkan bahwa pemilik kertas tersebut adalah pemilik perusahaan yang menerbitkan surat berharga tersebut. Porsi kepemilikan ditentukan oleh seberapa besar penyertaan yang ditanamkan di perusahaan tersebut [1].

Pasar yang memperjualbelikan saham dikenal dengan pasar saham. Informasi mengenai kinerja pasar saham diringkas dalam suatu indeks yang disebut indeks pasar saham (stocks market indexes). Salah satu contoh indeks pasar saham di Indonesia yaitu indeks LQ45. Indeks LQ45 merupakan indeks pasar saham yang terdiri dari 45 saham di Bursa Efek Indonesia (BEI) dengan likuiditas yang tinggi dan kapitalisasi pasar yang besar serta lolos seleksi menurut beberapa kriteria pemilihan [7].

Return merupakan pengembalian atau hasil yang diperoleh investor dari kegiatan investasi. Return digunakan sebagai salah satu pengukur kinerja dari investasi [4]. Hal lain yang berkaitan erat dengan return adalah ekspektasi return yang lebih mengacu kepada harapan harapan para investor atas besar pendapatan mereka di masa yang akan datang [5].

\subsection{Return dan Ekspektasi Return Saham Individu}

Return saham individu merupakan tingkat pengembalian dari investasi suatu saham [4]. Return saham pada waktu $t\left(R_{t}\right)$ dapat dihitung sebagai berikut

$$
R_{t}=\frac{S_{t}-S_{t-1}}{S_{t-1}}, \text { untuk } t=2,3, \cdots, n,
$$

Ekspektasi return saham $(E(R))$ dapat dihitung dengan

$$
E(R)=\frac{\sum_{t=1}^{n} R_{t}}{n}
$$

dengan

$S_{t}$ : harga saham pada waktu $t$,

$n$ : jumlah periode observasi data pergerakan harga saham.

\subsection{Return dan Ekspektasi Return Pasar}

Return pasar adalah tingkat pengembalian yang didasarkan pada perkembangan indeks harga saham. Indeks pasar yang dapat dipilih untuk pasar BEI misalnya 
adalah LQ45 [3]. Return pasar $\left(R_{M}\right)$ dapat dihitung sebagai berikut

$$
R_{M}=\frac{L Q 45_{t}-L Q 45_{t-1}}{L Q 45_{t-1}} \text { untuk } t=2,3, \cdots, n,
$$

Ekspektasi return pasar $\left(E\left(R_{M}\right)\right)$ dapat dihitung dengan

$$
E\left(R_{M}\right)=\frac{\sum_{t=1}^{n} R_{M}}{n}
$$

dimana

$$
\begin{aligned}
L Q 45_{t} & : \text { harga pasar LQ45 pada waktu } t \\
n & : \text { jumlah periode observasi data pergerakan harga pasar. }
\end{aligned}
$$

\subsection{Return Bebas Risiko}

Return bebas risiko merupakan tingkat pengembalian yang diperoleh dari aktiva bebas risiko. Sertifikat Bank Indonesia (SBI) merupakan salah satu aktiva bebas risiko [3]. Return bebas risiko $\left(R_{B R}\right)$ dapat dihitung sebagai berikut

$$
R_{B R}=\frac{\sum S B I_{i}}{n}
$$

dimana

$$
\begin{gathered}
S B I_{i}: \text { harga suku bunga Sertifikat Bank Indonesia bulan ke- } i, \\
n: \text { jumlah periode suku bunga Sertifikat Bank Indonesia. }
\end{gathered}
$$

\section{Capital Asset Pricing Model}

Capital Asset Pricing Model (CAPM) pertama kali diperkenalkan oleh Sharpe, Lintner, dan Mossin pada pertengahan tahun 1960-an. Model CAPM bertujuan untuk menentukan besarnya tingkat pengembalian yang diharapkan (expected return) dari investasi yang berisiko [3]. Asumsi-asumsi yang digunakan pada model CAPM yaitu:

(1) Semua investor mempunyai harapan atau ekspektasi yang homogen

(2) Semua investor mempunyai satu periode waktu yang sama

(3) Semua investor dapat meminjam (borrowing) atau meminjamkan (lending) uang pada tingkat return yang bebas risiko

(4) Tidak ada biaya transaksi, pajak pendapatan, dan inflasi

(5) Terdapat banyak investor, dan tidak ada satupun investor yang dapat mempengaruhi harga saham

(6) Semua aktiva dapat diperjualbelikan

(7) Pasar dalam kondisi seimbang (equilibrium).

Asumsi-asumsi di atas terlihat tidak realistis, akan tetapi CAPM merupakan model yang secara sederhana dapat menggambarkan realitas di pasar yang bersifat kompleks [6]. Apabila semua asumsi terpenuhi, maka akan terbentuk suatu pasar yang seimbang (equilibrium). Keadaan pasar yang mempengaruhi harga suatu saham akan mengakibatkan return dan risiko saham berubah seiring dengan keadaan pasar [7]. 
CAPM merupakan model yang digunakan untuk mengestimasi ekspektasi return dan risiko saham. Persamaan CAPM dituliskan sebagai berikut [3]:

$$
E\left(R_{i}\right)=R_{B R}+\left[E\left(R_{M}\right)-R_{B R}\right] \beta_{i}
$$

dimana

$$
\begin{aligned}
E\left(R_{i}\right) & : \text { ekspektasi return saham ke- } i, \\
E\left(R_{M}\right) & : \text { ekspektasi return pasar, } \\
R_{B R} & : \text { return bebas risiko, } \\
\beta_{i} & : \text { beta saham ke- } i
\end{aligned}
$$

Beta disebut juga sebagai risiko sistematis yang menunjukkan hubungan antara saham dengan pasarnya [2]. Beta adalah kovarians return saham dengan return return pasar yang distandarisasi dengan varians return pasar. Beta merupakan suatu pengukur volatilitas (volatility) return suatu saham terhadap return pasar. Beta pada saham ke- $i\left(\beta_{i}\right)$ dapat dihitung dengan rumus sebagai berikut [7]:

$$
\beta_{i}=\frac{\sigma_{i M}}{\sigma_{M}^{2}}
$$

dimana

$$
\begin{aligned}
\sigma_{i M} & : \text { kovarian return saham dengan return pasar, } \\
\sigma_{M}^{2} & : \text { varian return pasar. }
\end{aligned}
$$

\section{Data dan Metode}

\subsection{Data}

Data yang digunakan pada penelitian ini adalah data saham-saham yang diperdagangkan pada pasar modal melalui Bursa Efek Indonesia (BEI) yang masuk dalam daftar Indeks LQ45. Data historis harian diakses melalui https://finance.yahoo.com

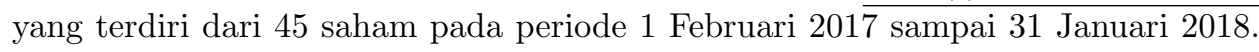
Dari 45 saham tersebut, dipilih saham-saham yang konsisten bergabung selama periode penelitian, sehingga diperoleh 39 saham yaitu AALI, ADHI, ADRO, AKRA, ANTM, ASII, BBCA, BBNI, BBRI, BBTN, BMRI, BSDE, GGRM, HMSP, ICBP, INCO, INDF, INTP, JSMR, KLBF, LPKR, LPPF, LSIP, MNCN, MYRX, PGAS, PTBA, PTPP, PWON, SCMA, SMGR, SMRA, SRIL, SSMS, TLKM, UNTR, UNVR, WIKA, dan WSKT.

\subsection{Metode}

Langkah-langkah yang dilakukan pada penelitian ini adalah:

(1) Menghitung tingkat pengembalian (return) saham individu $\left(R_{i}\right)$

(2) Menghitung ekspektasi return pasar

(3) Menghitung return bebas risiko

(4) Menghitung risiko sitematis atau beta masing-masing saham $\left(\beta_{i}\right)$

(5) Menghitung ekspektasi return masing-masing saham $\left(E\left(R_{i}\right)\right)$

(6) Menggambarkan Security Market Line 


\section{Hasil dan Pembahasan}

\subsection{Ekspektasi Return Pasar}

Nilai ekspektasi return pasar diperoleh dengan menghitung rata-rata dari nilai return harga pasar. Indeks pasar yang digunakan adalah Indeks LQ45, dengan ekspektasi return yang bernilai positif sebesar 0.000953. Hal ini menunjukkan bahwa return pasar bergerak ke arah yang positif dan pasar modal Indonesia mampu memberikan keuntungan rata-rata sebesar 0.000953 kepada investor selama periode penelitian.

\subsection{Return Bebas Risiko}

Aset bebas risiko yang digunakan dalam perhitungan return bebas risiko adalah suku bunga Sertifikat Bank Indonesia atau BI Rate periode Februari 2017 Januari 2018. Hasil analisis menunjukkan rata-rata per hari tingkat pengembalian bebas risiko di Indonesia sebesar 0.000124 .

\subsection{Risiko Sistematis atau Beta}

Beta menunjukkan hubungan antara tingkat pengembalian suatu saham dengan tingkat pengembalian pasar karena merupakan hasil bagi antara kovarian antara return saham dan return pasar dengan varian return pasar.

Tabel 1 menunjukkan nilai beta masing-masing saham. Sebanyak 10 saham dari 39 saham perusahaan memiliki $\beta_{i}$ lebih dari 1, dan 29 saham lainnya memiliki $\beta_{i}$ dengan nilai kurang dari 1 . Hal ini menjelaskan bahwa 10 saham perusahaan dengan beta yang lebih tinggi dari satu memiliki risiko sistematis yang lebih besar dari risiko pasar dan 29 saham perusahaan dengan beta yang lebih rendah dari satu memiliki risiko sistematis yang lebih kecil dari risiko pasar.

Saham PT Pakuwon Jati Tbk (PWON) merupakan saham paling agresif karena memiliki nilai beta saham paling tinggi, yaitu sebesar 1.407765. Saham PT Hanson International Tbk (MYRX) merupakan saham yang paling defensif karena memiliki nilai beta paling rendah sebesar 0.161132 .

\subsection{Ekspektasi Return Saham}

Ekspektasi return dari masing-masing saham dihitung dengan menggunakan persamaan Capital Asset Pricing Model. Hasil perhitungan dapat dilihat pada Tabel 2.

Dari Tabel 2 dapat dilihat bahwa semua saham memiliki ekspektasi return yang bernilai positif. Ini menggambarkan harga saham yang cenderung naik. Nilai ekspektasi return paling rendah dimiliki oleh saham PT Hanson International Tbk (MYRX) yaitu sebesar 0.000258. Sedangkan saham PT Pakuwon Jati Tbk (PWON) memiliki nilai ekspektasi return paling tinggi yaitu sebesar 0.001291. Saham perusahaan dengan nilai ekspektasi return tertinggi dan terendah sama dengan saham perusahaan dengan nilai beta tertinggi dan terendah. Hal ini membuktikan pernyataan bahwa semakin besar risiko yang ditanggung, maka semakin besar pula return yang akan didapatkan dalam berinvestasi pada suatu saham. 
Tabel 1. Hasil Perhitungan Beta Masing-masing Saham

\begin{tabular}{|c|c|c|c|c|c|}
\hline No & Kode Saham & $\beta_{i}$ & No & Kode Saham & $\beta_{i}$ \\
\hline 1 & AALI & 0.424221 & 21 & LPKR & 0.913009 \\
2 & ADHI & 0.779390 & 22 & LPPF & 1.147867 \\
3 & ADRO & 1.258012 & 23 & LSIP & 0.652272 \\
4 & AKRA & 0.767746 & 24 & MNCN & 0.455731 \\
5 & ANTM & 0.392502 & 25 & MYRX & 0.161132 \\
6 & ASII & 1.150328 & 26 & PGAS & 0.971895 \\
7 & BBCA & 0.832947 & 27 & PTBA & 0.555452 \\
8 & BBNI & 0.853994 & 28 & PTPP & 0.616194 \\
9 & BBRI & 1.170968 & 29 & PWON & 1.407765 \\
10 & BBTN & 0.543609 & 30 & SCMA & 0.670222 \\
11 & BMRI & 0.963919 & 31 & SMGR & 0.819119 \\
12 & BSDE & 0.752611 & 32 & SMRA & 1.282019 \\
13 & GGRM & 1.269062 & 33 & SRIL & 0.405621 \\
14 & HMSP & 1.383567 & 34 & SSMS & 0.199028 \\
15 & ICBP & 0.741323 & 35 & TLKM & 0.953424 \\
16 & INCO & 0.378974 & 36 & UNTR & 1.387134 \\
17 & INDF & 0.724219 & 37 & UNVR & 0.833107 \\
18 & INTP & 1.166146 & 38 & WIKA & 0.638601 \\
19 & JSMR & 0.798686 & 39 & WSKT & 0.619188 \\
20 & KLBF & 0.800112 & & & \\
\hline \multicolumn{7}{|c|}{} \\
\hline
\end{tabular}

\subsection{Penggambaran Security Market Line}

Data yang diperlukan untuk membuat Security Market Line adalah beta dan ekspektasi return.

Pada Gambar 1 Security Market Line terbentuk dengan menghubungkan titiktitik beta dan ekspektasi return berdasarkan urutan beta dari angka yang terkecil. Security Market Line ini memiliki slope yang positif karena semakin besar nilai beta, semakin besar pula nilai tingkat imbal hasil yang diharapkan. Hal ini terlihat dari pergerakan garis yang mengarah ke kanan atas.

\section{Kesimpulan}

Berdasarkan penelitian dan hasil dari analisis data selama periode Februari 2017 sampai Januari 2018 pada saham yang tergabung dalam Indeks LQ45, diperoleh semua saham memiliki nilai beta dan ekspektasi return positif yang berarti harga saham cenderung naik. Selain itu, diketahui bahwa saham PT Pakuwon Jati Tbk (PWON) memiliki nilai beta tertinggi sebesar 1.407765 serta ekspektasi return tertinggi sebesar 0.001291. Saham PT Hanson International Tbk (MYRX) memiliki beta dan ekspektasi return terendah di antara 39 saham lainnya dengan nilai masing-masing sebesar 0.161132 dan 0.000258 . Hasil ini menunjukkan bahwa hubungan antara risiko sistematis dan tingkat pengembalian yang diharapkan dari 
Tabel 2. Hasil Perhitungan Ekspektasi Return Masing-masing Saham

\begin{tabular}{|c|c|c|c|c|c|}
\hline No & Kode Saham & $E\left(R_{i}\right)$ & No & Kode Saham & $E\left(R_{i}\right)$ \\
\hline 1 & AALI & 0.000476 & 21 & LPKR & 0.000881 \\
2 & ADHI & 0.000770 & 22 & LPPF & 0.001076 \\
3 & ADRO & 0.001167 & 23 & LSIP & 0.001076 \\
4 & AKRA & 0.000760 & 24 & MNCN & 0.000502 \\
5 & ANTM & 0.000449 & 25 & MYRX & 0.000258 \\
6 & ASII & 0.001078 & 26 & PGAS & 0.000930 \\
7 & BBCA & 0.000815 & 27 & PTBA & 0.000584 \\
8 & BBNI & 0.000832 & 28 & PTPP & 0.000635 \\
9 & BBRI & 0.001095 & 29 & PWON & 0.001291 \\
10 & BBTN & 0.000575 & 30 & SCMA & 0.000680 \\
11 & BMRI & 0.000923 & 31 & SMGR & 0.000803 \\
12 & BSDE & 0.000748 & 32 & SMRA & 0.001187 \\
13 & GGRM & 0.001176 & 33 & SRIL & 0.000460 \\
14 & HMSP & 0.001271 & 34 & SSMS & 0.000289 \\
15 & ICBP & 0.000739 & 35 & TLKM & 0.000914 \\
16 & INCO & 0.000438 & 36 & UNTR & 0.001274 \\
17 & INDF & 0.000724 & 37 & UNVR & 0.000815 \\
18 & INTP & 0.001091 & 38 & WIKA & 0.000653 \\
19 & JSMR & 0.000786 & 39 & WSKT & 0.000637 \\
20 & KLBF & 0.000787 & & & \\
\hline \multicolumn{7}{|r|}{} \\
\hline
\end{tabular}

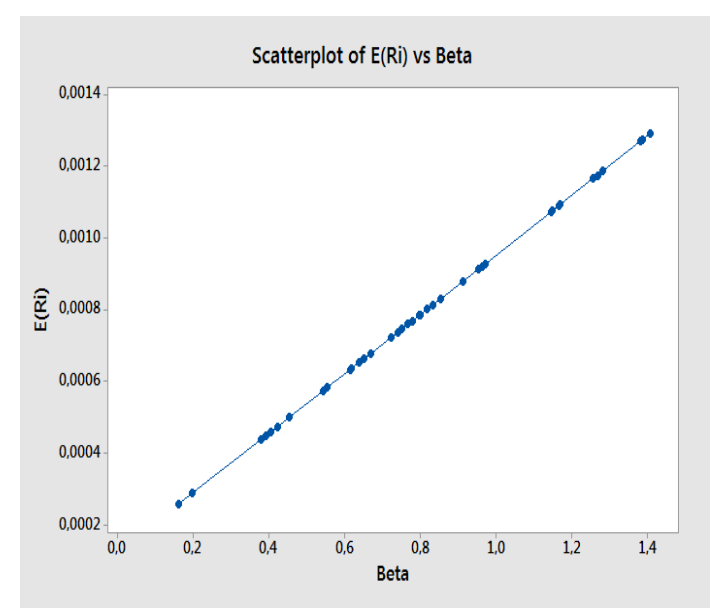

Gambar 1. Security Market Line

investasi bersifat positif dan linier. 
Cindyana Aldrifisia, dkk.

\section{Daftar Pustaka}

[1] Darmadji, T. dan H.M. Fakhruddin. 2001. Pasar Modal di Indonesia. Salemba Empat, Jakarta.

[2] Fahmi, I. 2015. Pengantar Teori Portofolio dan Analisis Investasi. Alfabeta, Bandung.

[3] Hartono, J. 2015. Teori Portofolio dan Analisis Investasi. Edisi Kesepuluh. BPFE-Yogyakarta, Yogyakarta.

[4] Husnan, S. 1998. Dasar-Dasar Teori Portofolio dan Analisis Sekuritas. Edisi Ketiga. UPP AMP YKPM, Yogyakarta.

[5] Lasmanah. dan E. Diptyoadi. 2008. Penyusunan Portofolio Optimal dengan Metode Capital Asset Pricing Model pada Saham-saham Sektor Keuangan di PT.BEJ. Jurnal Bisnis, Manajemen, dan Ekonomi. 9: 1768

[6] Perold, Andre F. 2004. The Capital Asset Pricing Model. Journal of Economics Perspectives. 18: $15-16$

[7] Tandelilin, Eduardus. 2010 EPortofolio dan Investasi. Edisi Pertama. Kanisius, Yogyakarta. 